\title{
Skin Absorption of Toluene, Styrene, and Xylene by Man
}

\author{
TADEUSZ DUTKIEWICZ and HALINA TYRAS
}

From the Department of Toxicological Chemistry and Industrial Toxicology, Medical Academy, Lódz, Poland

\section{Toluene $^{1}$}

We have investigated the skin absorption of liquid toluene and of solutions of toluene in water by the methods we used for ethylbenzene (Dutkiewicz and Tyras, 1967). The absorption rate of liquid toluene was $14-23 \mathrm{mg} . / \mathrm{cm} .{ }^{2} / \mathrm{hr}$ in 10 estimations on nine subjects. Absorption of toluene from an aqueous solution was proportional to the concentration (Figure). For equal concentrations the rate was only a little less than that of ethylbenzene. Very short exposure of the hands to liquid toluene (a few minutes) or more prolonged exposure (about one hour) to water saturated with toluene causes the absorption of as much toluene as an eight-hour exposure to the maximum allowable concentration of $0.1 \mathrm{mg}$./litre of air. ${ }^{2}$

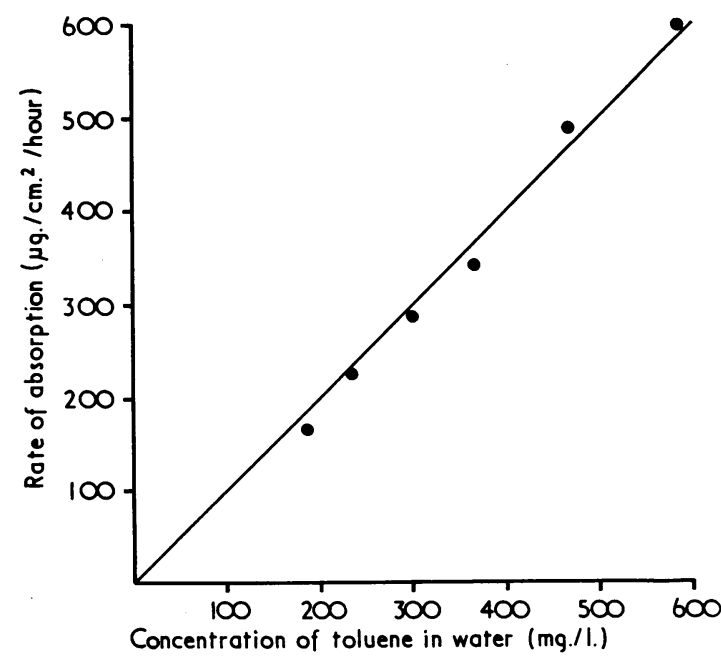

FIGURE. Rate of absorption of toluene as a function of the concentration in water.

\footnotetext{
${ }^{1}$ Received for publication October 10, 1967

${ }^{2}$ The M.A.C. for toluene accepted in Poland (Orders of Ministry Council, August 2 I, 1959, r. Dz. Ust. 53, poz. 316) is $0.1 \mathrm{mg}$./litre. This is equivalent to 26.6 parts per million.
}

\section{Styrene $^{3}$}

The absorption of styrene through the skin of the hand and the forearm in man was investigated experimentally. Both the absorption of liquid styrene and the absorption from aqueous solutions were studied by the method of Dutkiewicz and Tyras (1967). The rate of absorption of liquid styrene was 9 to $15 \mathrm{mg} . / \mathrm{cm}^{2} / \mathrm{hr}$, and the rates from aqueous solutions were $40-180 \mu \mathrm{g} . / \mathrm{cm} .^{2} / \mathrm{hr}$ for mean concentrations of $66 \cdot 5-269 \mathrm{mg}$./litre. Absorption of styrene from solution was linear with concentration. The mandelic acid excreted in urine was equivalent to about $13 \%$ of the absorbed dose-much less than after lung absorption. Very short exposure of the hands to liquid styrene (a few minutes) or more prolonged exposure (about one hour) to water saturated with styrene may result in the absorption of as much styrene as an 8-hour exposure to the maximum allowable concentration of $0.05 \mathrm{mg}$./litre of air. ${ }^{4}$

Urinary mandelic acid does not provide a reliable index of absorption where there is simultaneous skin and lung exposure.

\section{Xylene $^{5}$}

The absorption of liquid xylene through the skin in man was investigated under experimental conditions (Dutkiewicz and Tyras, 1967). Using the direct method, experiments of absorption were carried out on the skin of the forearms of ro different volunteers.

It has been established that the rate of absorption of liquid xylene was from 4.5 to $9.6 \mathrm{mg}$. $/ \mathrm{cm} .{ }^{2} /$ hour.

\section{REFERENCE}

Dutkiewicz, T., and Tyras, H. (1967). A study of the skin absorption of ethylbenzene in man. Brit. F. industr. Med., 24, 330-332.

${ }^{3}$ Received for publication March 20, 1968

${ }^{4}$ The M.A.C. for styrene accepted in Poland (Orders of Ministry Council, August 21, 1959, r. Dz. Ust. 53, poz. 316) is $0.05 \mathrm{mg}$./litre.

${ }^{5}$ Received for publication March 20, 1968 